\title{
Biological activities and biomedical potential of sea cucumber (Stichopus japonicus): a review
}

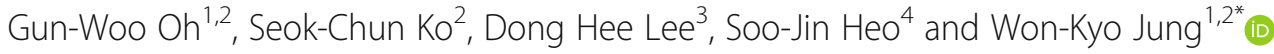

\begin{abstract}
Members of the phylum Echinodermata, commonly known as echinoderms, are exclusively marine invertebrates. Among the Echinodermata, sea cucumber belongs to the family Holothuroidea. The sea cucumber Stichopus (Apostichous) japonicus (Selenka) is an invertebrate animal inhabiting the coastal sea around Korean, Japan, China, and Russia. Sea cucumber has a significant commercial value, because it contains valuable nutrients such as vitamins and minerals. They possess a number of distinctive biologically and pharmacologically important compounds. In particular, the body wall of sea cucumber is a major edible part. It consists of peptide, collagen, gelatin, polysaccharide, and saponin, which possess several biological activities such as anti-cancer, anti-coagulation, anti-oxidation, and antiosteoclastogenesis. Furthermore, the regenerative capacity of sea cucumber makes it a medically important organism. This review presents the various biological activities and biomedical potential of sea cucumber S. japonicus.
\end{abstract}

Keywords: Biomedical potential, Biological activities, Marine invertebrate, Sea cucumber, Stichopus japonicus

\section{Background}

Members of the phylum Echinodermata, commonly known as echinoderms, are exclusively marine invertebrates. There are about 7000 species of echinoderms worldwide and are divided into five classes including crinoids, asteroids, ophiuroids, echinoids and holothuroids (Dupont et al. 2010). Echinoderms occupy an important evolutionary position in understanding the origin and evolution of vertebrates (Du et al. 2012). Sea cucumber belongs to the family Holothuroidea. The majority of sea cucumber are deposit feeders and, play important roles in aquaculture system as environmental cleaners because they swallow the sediments, organic matter extracts, protozoa, benthic microalgae, and detritus of macroalgae (Gao et al. 2011b; Yang et al. 2006). Approximately 1250 species of sea cucumber have been identified on the sea floor worldwide, of which about 20 species are edible (Jo et al. 2016).

\footnotetext{
* Correspondence: wkjung@pknu.ac.kr

${ }^{1}$ Department of Biomedical Engineering, and Center for Marine-Integrated Biomedical Technology (BK21 Plus), Pukyong National University, Busan 48513, Republic of Korea

${ }^{2}$ Marine-Integrated Bionics Research Center, Pukyong National University,

Busan 48513, Republic of Korea

Full list of author information is available at the end of the article
}

In particular, the sea cucumber Stichopus (Apostichous) japonicus (Selenka) is an invertebrate animal inhabiting the coastal sea around Korean, Japan, China, and Russia from a latitude of $35^{\circ} \mathrm{N}$ to at least $44^{\circ} \mathrm{N}$ (Kan-no and Kijima 2003; Bai et al. 2015). It is one of the highest commercially valuable species as seafood, and based on its color, it is divided into three groups such as red, green, and black. The color variation affects the price and taste of the sea cucumber products; the red sea cucumber is more expensive than the green or black one ( $\mathrm{Li}$ and $\mathrm{Li} 2010$ ). The body wall of the sea cucumber is a major edible part and consists mainly of collagen and mucopolysaccharides (Duan et al. 2010). In addition, the body wall with peptide, collagen, gelatin, polysaccharide, and saponin has several biological activities such as anticancer, anticoagulation, anti-oxidation, and anti-osteoclastogenesis (Kariya et al. 2004; Lu et al. 2010; Zhou et al. 2012; Yang et al. 2015a). Furthermore, sea cucumbers have high applications in the biomedical field because of their regenerative capacities as they can regenerate tissues and organs within a few months (Zohdi et al. 2011). 
Food industrial importance of sea cucumber

Sea cucumber fisheries have rapidly expanded worldwide in the catch and value over the past two to three decades (Anderson et al. 2011). It has a significant commercial value because it has high valuable nutrient content of vitamins and minerals, and a number of distinctive biologically and pharmacologically bioactive compounds. Sea cucumber provides a source of nutrition to perhaps more than one billion Asian consumers and around $10,000 \mathrm{t}$ of dried sea cucumber is traded internationally per annum (Purcell et al. 2016). They are usually processed into a frozen, cooked-dried, cooked-salted, and cooked-salted-dried products (Aydin et al. 2011). However, almost sea cucumber exported in dried products form and a small quantity of fresh and frozen products form. Nearly $90 \%$ of this trade takes place in the Asian Far East where China Hong Kong SAR and Singapore dominate the business and China PR remains the main consuming country (Ferdouse 2004).

The proximate composition of sea cucumbers differs depending upon the seasonal variations, geographical location, and feeding regimes. Table 1 shows that moisture of wet sea cucumber and protein, ash, and fat contents of dried sea cucumber vary from 90.8 to $93.4,29.9$ to $48.1,18.4$ to 47.8 , and 1.3 to $7.0 \%$, respectively. In addition, proximate composition of wet matter showed that moisture, protein, ash, fat, and carbohydrates contents of dried sea cucumber vary from 80.2 to $93,1.1$ to 5.4, 2.4 to $6.9,0.1$ to 2.2 and 0.2 to $0.6 \%$, respectively.

\section{Bioactive components and pharmaceutical industrial importance of sea cucumber}

Many marines derived naturally compounds are of great interest for a potential new ingredient for various industrial applications. Among the marine invertebrate, sea cucumbers are one of the potential high food and medicinal in Asia and reported with relatively high economic and food value. They have been recognized in folk medicine systems of Asian countries and as having an impressive range of medicinal health functions for nourishing the body, detoxifying the kidneys, moistening dryness of the intestines, treatment of stomach ulcers, asthma, antihypertension, rheumatism and wound healing (Alves RRN, and Rosa IL 2012). The therapeutic properties and medicinal benefits of sea cucumbers can be linked to the presence of a wide array of bioactive (Bordbar et al. 2011). Nutritionally, a number of unique biological and pharmacological activities and have various bioactive components such as peptides, fatty acids, glycosaminoglycan (chondroitin/fucan sulfates), nortriterpene/triterpene glycosides, other extracts, and hydrolysates (Table 2). A number of important bioactive compounds identified in $S$. japonicus are listed in Table 3.

\section{Biological activities \\ a-Glucosidase inhibition}

Diabetes is one of the most serious, chronic disease and causes enormous human suffering in the form of blindness, kidney failure, amputations, and increased risk of coronary artery disease and stroke (Taylor 1999). There are two common forms of diabetes: type 1 diabetes, which is insulin dependent, and type 2, which is noninsulin dependent. Type 2 diabetes is the most common form, accounting for $90-95 \%$ of all cases of diabetes (Moller 2001). In type 2 diabetes, control of glucose level is a major focus in disease management. $\alpha$-Glucosidase is a key carbohydrate-hydrolyzing enzymes involved in carbohydrate breakdown and absorption in the digestive tract (Heo et al. 2009). Therefore, $\alpha$-glucosidase inhibitor such as acarbose, miglitol, and voglibose are widely used

Table 1 Proximate composition of sea cucumber Stichopus japonicus in the various papers

\begin{tabular}{llllll}
\hline Water (\%) & Protein (\%) & Ash (\%) & Lipid (\%) & Carbohydrate (\%) & Ref. \\
\hline $92-93^{\mathrm{a}}$ & $2.2-3.4^{\mathrm{a}}$ & $2.7-3.4^{\mathrm{a}}$ & $0.1-0.4^{\mathrm{a}}$ & - & (Dong et al. 2006) \\
$92.1-93.4^{\mathrm{a}}$ & $30.0-37.9^{\mathrm{b}}$ & $38.7-44.2^{\mathrm{b}}$ & $2.9-7.0^{\mathrm{b}}$ & - & (Okorie et al. 2008) \\
$92.1-92.9^{\mathrm{a}}$ & $29.9-32.8^{\mathrm{b}}$ & $39.5-47.8^{\mathrm{b}}$ & $2.8-5.4^{\mathrm{b}}$ & - & (Ko et al. 2009) \\
$92.3^{\mathrm{a}}$ & $3.1^{\mathrm{a}}$ & $3.6^{\mathrm{a}}$ & $0.3^{\mathrm{a}}$ & - & (Choi et al. 2009) \\
- & $32-33^{\mathrm{b}}$ & $45-46^{\mathrm{b}}$ & $1.3-2.1^{\mathrm{b}}$ & - & (Seo et al. 2011) \\
$90.5-91.7^{\mathrm{a}}$ & $4.1-4.6^{\mathrm{a}}$ & $2.4-2.6^{\mathrm{a}}$ & $0.2^{\mathrm{a}}$ & $0.2^{\mathrm{a}}$ & (Jiang et al. 2013) \\
$80.2-91.5^{\mathrm{a}}$ & $1.1-4.0^{\mathrm{a}}$ & $2.5-6.9^{\mathrm{a}}$ & $0.1-2.2^{\mathrm{a}}$ & - & (Lee et al. 2012) \\
$89.0-91.9^{\mathrm{a}}$ & $3.5-5.4^{\mathrm{a}}$ & $2.9-3.4^{\mathrm{a}}$ & $0.1-0.5^{\mathrm{a}}$ & $0.2-0.6^{\mathrm{a}}$ & (Gao et al. 2011a) \\
$90.8-91.2^{\mathrm{a}}$ & $45.1-46.1^{\mathrm{b}}$ & $32.2-33.9^{\mathrm{b}}$ & $4.3-5.2^{\mathrm{b}}$ & - & (Wu et al. 2015) \\
$93.2-93.3^{\mathrm{a}}$ & $44.9-48.1^{\mathrm{b}}$ & $18.4-26.5^{\mathrm{b}}$ & $3.4-4.1^{\mathrm{b}}$ & - & (Yu al. 2015a) \\
$90.1-91.6^{\mathrm{a}}$ & $4.3-4.6^{\mathrm{a}}$ & $2.4-2.7^{\mathrm{a}}$ & $0.1-0.3^{\mathrm{a}}$ & - & (Xia et al. 2015) \\
\hline
\end{tabular}


Table 2 Various biological activities of sea cucumber Stichopus japonicus component

\begin{tabular}{|c|c|c|c|c|}
\hline$\overline{\text { Activities }}$ & Extraction methods & Active compounds & Color & Ref. \\
\hline a-Glucosidase & Organic solvent $(80 \% \mathrm{MeOH})$ & $\begin{array}{l}n \text {-Hexane fraction } \\
\text { (Unsaturated fatty acids) }\end{array}$ & - & (Nguyen et al. 2011) \\
\hline \multirow[t]{2}{*}{ Anti-coagulation } & Hydrolysis (Diastase vera) & Glycosaminoglycan & - & (Yang et al. 2015b) \\
\hline & Hydrolysis (Diastase vera) & Glycosaminoglycan & - & (Yang et al. 2015a) \\
\hline \multirow[t]{3}{*}{ Anti-cancer } & - & Acid mucopolysaccharide & - & (Lu et al. 2010) \\
\hline & Organic solvent (80\% EtOH) & $\mathrm{CH} 2 \mathrm{Cl} /$ /EtOAc fraction & Red & (Park et al. 2011) \\
\hline & Organic solvent $(70 \%$ EtOH) & Extracts & - & (Kim et al. 2017) \\
\hline Anti-fungal activity & Organic solvent $(60 \%$ EtOH) & $\begin{array}{l}n \text {-BuoH fraction } \\
\text { (Nortriterpene/triterpene glycosides) }\end{array}$ & - & (Wang et al. 2012) \\
\hline Anti-hyperlipidemic activity & Hydrolysis (Papain) & Polysaccharide & - & (Liu et al. 2012b) \\
\hline \multirow[t]{2}{*}{ Anti-inflammation } & Organic solvent $(\mathrm{MeOH})$ & EtOAc fraction & - & (Himaya et al. 2010) \\
\hline & Organic solvent (80\% EtOH) & EtOAc fraction & Red & (Park et al. 2011) \\
\hline \multirow[t]{3}{*}{ Anti-melanogenesis } & Organic solvent (80\% EtOH) & EtOAc fraction & Red & (Yoon et al. 2010) \\
\hline & Water/70\% EtOH & Adenosine/ethyl-a-D-glucopyranoside & - & (Husni et al. 2011) \\
\hline & Organic solvent (65\% EtOH) & Extracts & Red & (Oh et al. 2017) \\
\hline Anti-osteoclastogenesis & Chloroform/methanol & Fucan sulfates & - & (Kariya et al. 2004) \\
\hline \multirow[t]{6}{*}{ Anti-oxidation } & Water/70\% EtOH & Crude saponin & - & (Husni et al. 2009) \\
\hline & Hydrolysis (Flavourzyme) & Gelatin & - & (Wang et al. 2010) \\
\hline & Hydrolysis (Trypsin) & Peptide & - & (Zhou et al. 2012) \\
\hline & Hydrolysis (Pepsin) & Collagen & - & (Zhu et al. 2012) \\
\hline & Hydrolysis (Papain) & Polysaccharide & - & (Lui et al., 2012b) \\
\hline & Mcllvaines buffer & Peptide & - & (Zheng et al. 2012) \\
\hline \multirow[t]{2}{*}{ Immunomodulatory effect } & - & Acid mucopolysaccharide & - & (Song et al. 2013) \\
\hline & Water & Protein-sulfated fucan complex & - & (Cao et al. 2017) \\
\hline \multirow[t]{3}{*}{ Proliferative effect } & Hydrolysis (Pepsin/trypsin) & Polysaccharide & - & (Zhang et al. 2010b) \\
\hline & Hydrolysis (Pepsin/trypsin) & Polysaccharide & - & (Sheng et al. 2011) \\
\hline & Hydrolysis (Pepsin) & Collagen & Red & (Park et al. 2012) \\
\hline \multirow[t]{8}{*}{ Neural related activities } & Hydrolysis (Pepsin/trypsin) & Polysaccharide & - & (Cui et al. 2016c) \\
\hline & Organic solvent $\left(\mathrm{CHCl}_{3} / \mathrm{MeOH}\right)$ & Ganglioside & - & (Kaneko et al. 2003) \\
\hline & Hydrolysis (Pepsin/trypsin) & Polysaccharide & - & (Cui et al. 2016a) \\
\hline & Hydrolysis (Pepsin/trypsin) & Polysaccharide & - & (Sheng et al. 2012) \\
\hline & Hydrolysis (Pepsin/trypsin) & Polysaccharide & - & (Zhang et al. 2010a) \\
\hline & Hydrolysis (Pepsin/trypsin) & Polysaccharide/fucoidan/Heparin & - & (Cui et al. 2016b) \\
\hline & Hydrolysis (Pepsin/trypsin) & Polysaccharide & - & (Cui et al. 2015) \\
\hline & Hydrolysis (Protease N Amano G) & Chondroitin sulfate & - & (Shida et al. 2017) \\
\hline
\end{tabular}

in the treatment of patients with type 2 diabetes to prevent the breakdown and absorption of carbohydrates after food uptake. However, $\alpha$-glucosidase inhibitor has gastrointestinal side effects such as flatulence, diarrhea and abdominal cramps (Chiasson et al. 2002).

Nguyen et al. (2011) determined that two unsaturated fatty acids from n-hexane fraction of sea cucumber body wall inhibit $\alpha$-glucosidase activities. The two isolated unsaturated fatty acids were structurally identified using NMR and EI-MS. The two unsaturated fatty acids are identified as $7(\mathrm{Z})$-octadecenoic acid and $7(\mathrm{Z}), 10(\mathrm{Z})$-octadecadienoic acid. These unsaturated fatty acids showed a dose dependent inhibition of $\alpha$-glucosidase through mixed inhibition. In particular, $7(\mathrm{Z}), 10(\mathrm{Z})$-octadecadienoic acid was found to be a more effective $\alpha$-glucosidase inhibitor than $7(\mathrm{Z})$-octadecenoic acid. Therefore, these two unsaturated fatty acids can potentially be developed as a novel natural pharmaceutical agent. 


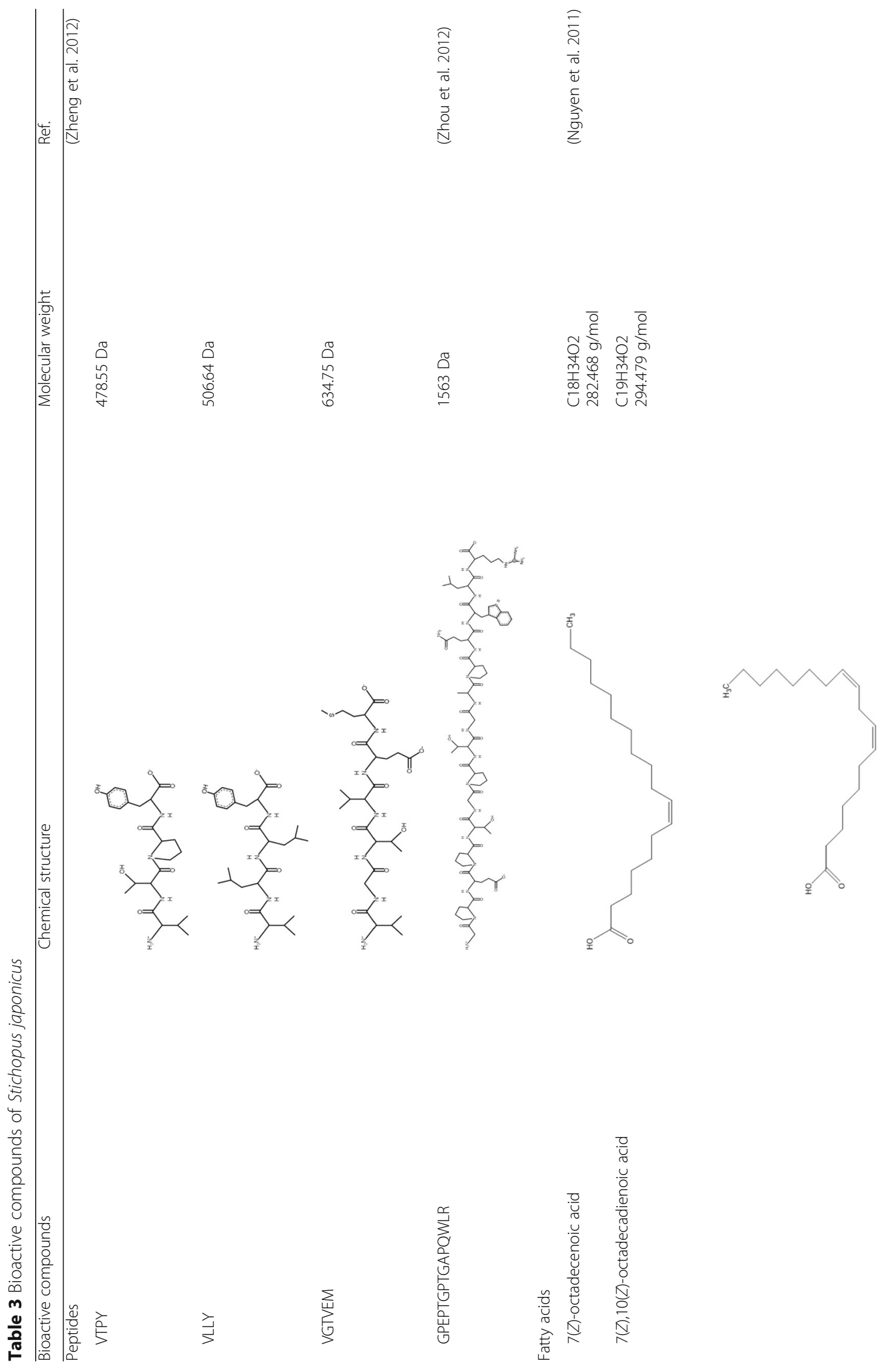




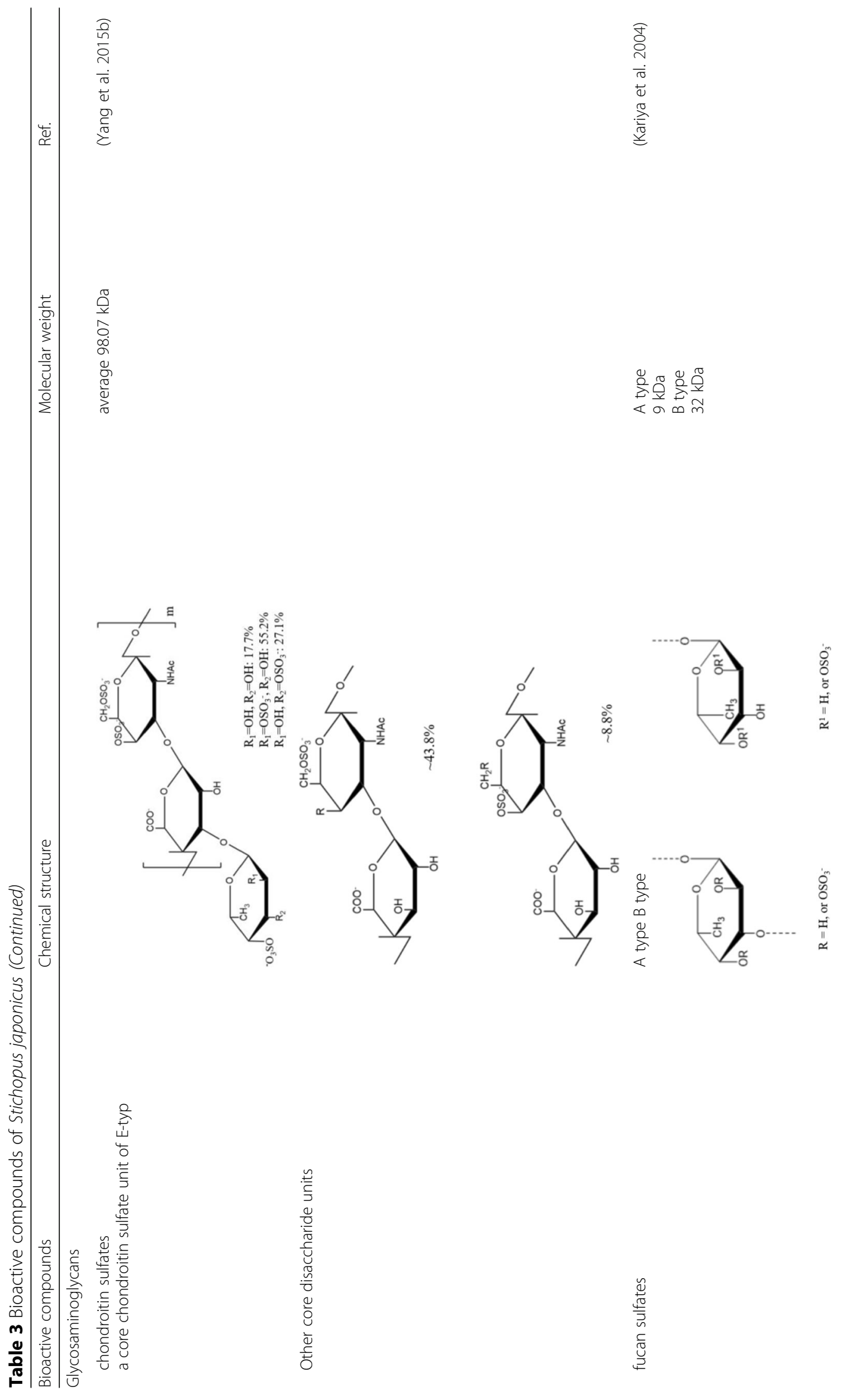




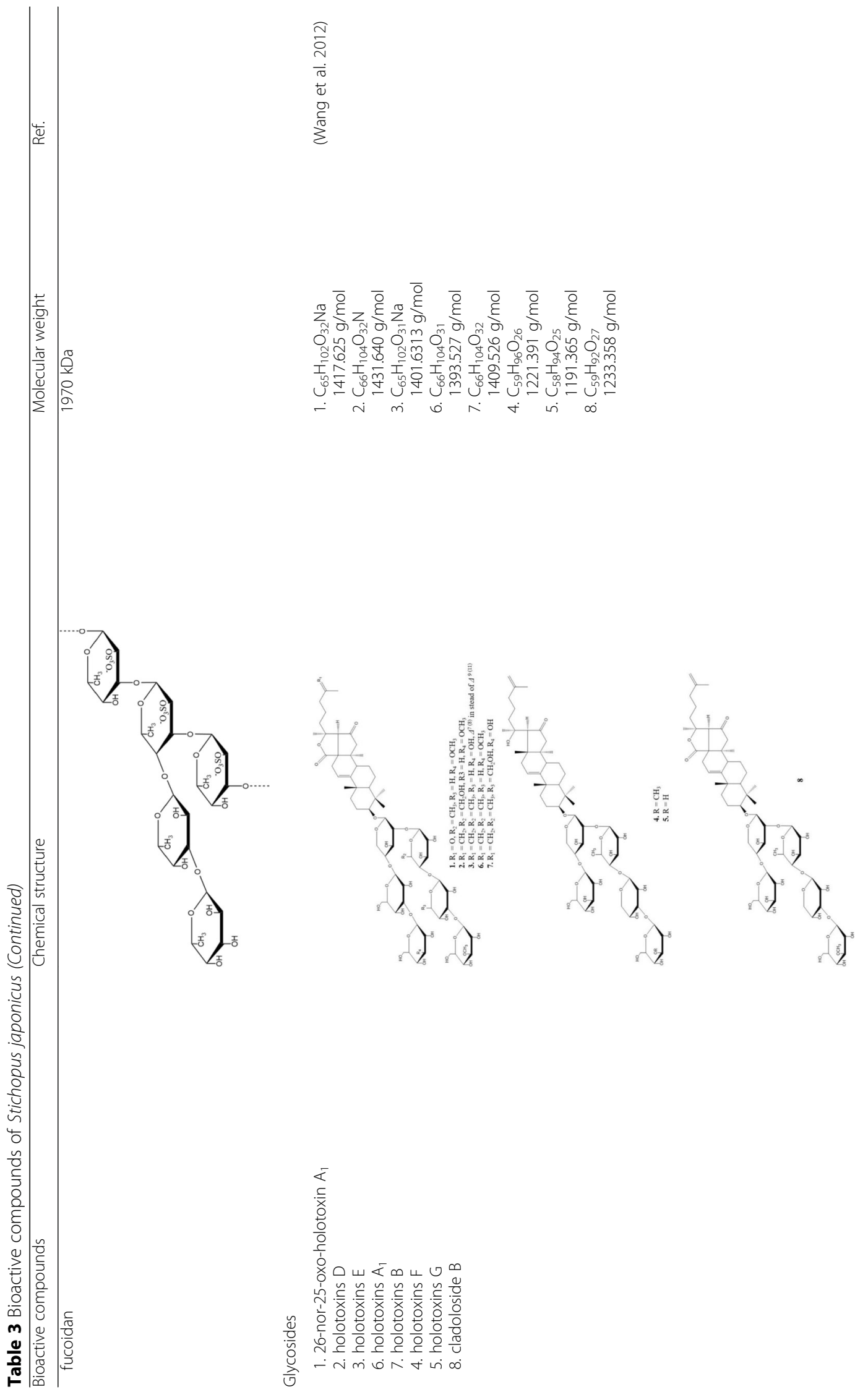




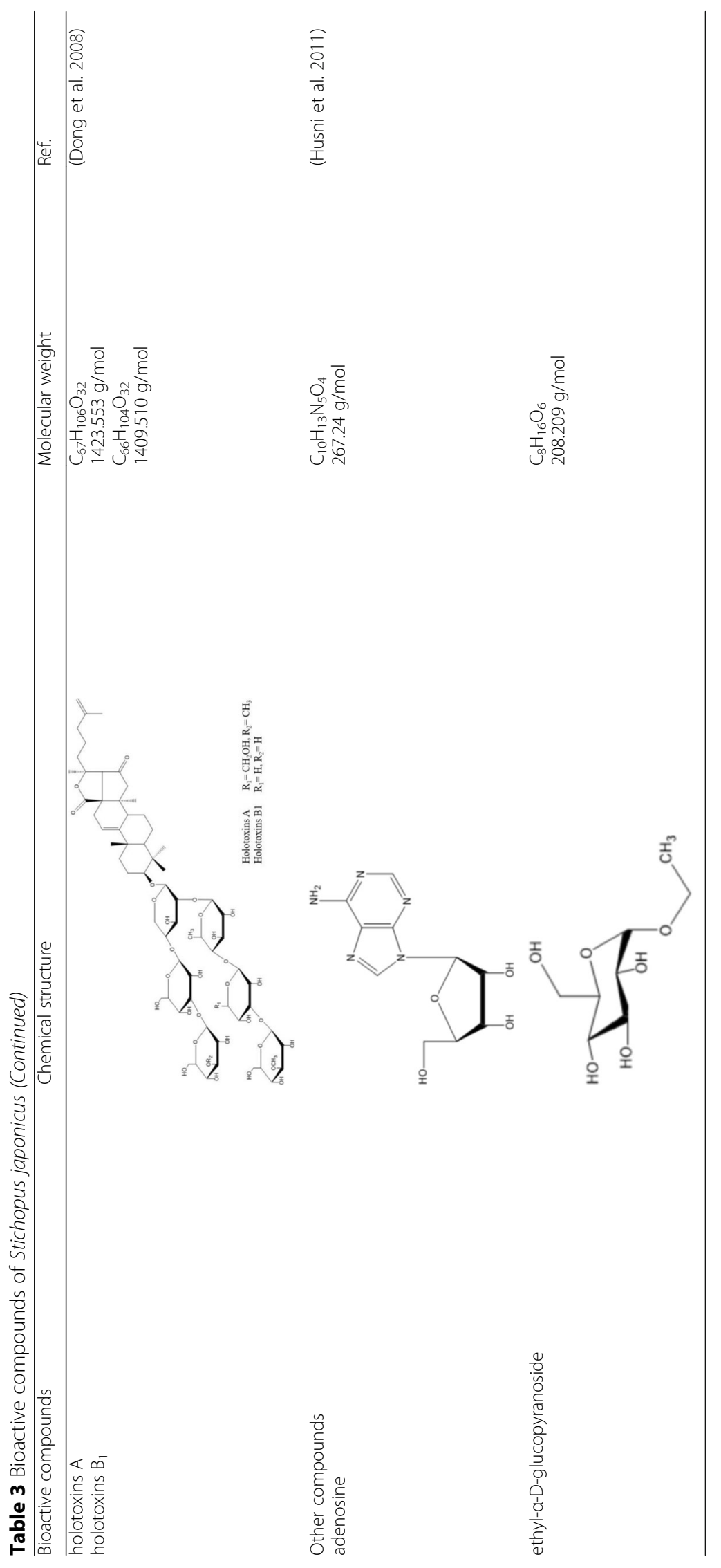




\section{Anti-cancer}

Cancer is a disease in which continuous clonal expansion of somatic cells causes death by invading, subverting, and eroding the normal tissues (Evan and Vousden 2001). Abnormal cell cycle regulation can result in cancerous growth and developmental abnormalities by uncontrolled growth and proliferation of cells (Maddika et al. 2007). The important control of cancer is the inhibition of abnormal cell growth and cell proliferation by anti-cancer agents.

The some sea cucumber S. japonicus has been reported a potential source of anti-cancer drugs. Park et al. (2011) extracted S. japonicus with different solvents and evaluated the anti-cancer activity in HL-60 and HT29 cells. Among the solvent extracts, EtOAc fractions showed higher cell growth inhibition than other solvent fractions. In the protein expression, EtOAc fractions decreased the prototypic anti-apoptotic protein (Bcl-2) and increased the cleaved caspase- 3 and poly (ADP-ribose) polymerase (PARP). In another study, Lu et al. (2010) extracted acid mucopolysaccharide from S. japonicus (SJAMP) and examined the apoptosis effect against human hepatocellular carcinoma cell line HepG2. The results showed that SJAMP inhibited the HepG2 cell proliferation and induced apoptosis by down-regulation of Bcl-2 and up-regulation of $\mathrm{nm} 23-\mathrm{H} 1$ gene expression in a time and dose dependent manner. In addition, Kim et al. (2017) extracted through ultrasonification extraction process at $50{ }^{\circ} \mathrm{C}$ and $95 \mathrm{kHz}$ for $2 \mathrm{~h}$ (UE) and investigated the anti-skin cancer activities compared with those from conventional extraction process in human skin malignant melanocytomas (SK-Mel-2) cells. The results showed that UE extracts inhibited the SK-Mel-2 cell proliferation and metastasis through reduction the expression of skin tumor-promoting genes such as Bcl-2, STAT3, and MMP-9. These reports suggest the use of the sea cucumber $S$. japonicus as a natural source of the potential anticancer drug.

\section{Anti-coagulation}

Coagulation also known as clotting is a hemostatic system that prevents of blood loss from the damaged blood vessels and keeps blood in a fluid state through the rapid formation of a clot (Mackman et al. 2007). The coagulation process is initiated as a result of the conversion of prothrombin to thrombin in the presence of calcium by releasing tissue factor (also known as thromboplastin) from damaged vessels (Versteeg et al. 2013). Thrombin is a key enzyme in the coagulation process and is produced by a tightly regulated series of reactions through the formation of the factor Xa/Va complex (Gailani and Renné 2007). The prothrombin time (PT) and activated partial thromboplastin time (APTT) are used to the screening coagulation assays in clinical practice for determining extrinsic or intrinsic coagulation pathways (Gailani and Renné 2007). Normally, anticoagulants such as heparin are used for the prevention of blood clotting during vascular surgery. However, heparin can cause a number of side effects such as osteoporosis, thrombocytopenia, increased functional activity of platelets and hemorrhagic complications (Mestechkina and Shcherbukhin 2010). Therefore, there is a need to replace heparin with new safe anticoagulants.

Yang et al. (2015a) isolated a novel depolymerized fucosylated chondroitin sulfate from S. japonicus (DAHG) by $\mathrm{Cu}^{2+}$ catalytic free-radical depolymerization and demonstrated its anticoagulant activities compared with low molecular weight heparin (LMWH; average molecular weight $3500 \mathrm{Da})$. The DAHG was fractionated into three different low molecular weight fractions such as DAHG-1 $(41,149 \mathrm{Da}), \quad$ DAHG-2 (24,755 Da) and DAHG-3 (8871 Da). During APTT assay, DAHG-2 and LMWH were shown to have almost the same anticoagulant activity. In addition, DAHG-2 had significantly less bleeding risk compared with LMWH at an equivalent concentration. Therefore, DAHG-2 could be used as a novel natural anticoagulant with fewer side effects. In another study, a novel glucosidic pattern of fucose (AHG; molecular weight $98,070 \mathrm{Da}$ ) was found in the glycosaminoglycan and AHG structure was elucidated by $1 / 2$ dimension NMR (Yang et al. 2015b). The anticoagulant activities were performed by APTT and thrombin time (TT) assays. For APTT activity, the concentration of AHG less than $170 \mu \mathrm{g} / \mathrm{ml}$ showed to have almost the same anticoagulant activity as that by unfractionated heparin. However, the higher AHG concentration of $170 \mu \mathrm{g} / \mathrm{ml}$ showed slightly lower anticoagulant activity compared to that by the unfractionated heparin. In the case of TT activity, AHG has slightly higher anticoagulant activity than heparin, suggesting that AHG isolated from $A$. japonicus could be used a potential anticoagulant drug.

\section{Anti-fungal activity}

In the past two decades, the incidence of invasive fungal infection has continued to increases. These fungal infections are major causes of morbidity and mortality in neutropenic patients which includes individuals undergoing organ, blood, and marrow transplantation, and those receiving intensive chemotherapy or other immunosuppressive treatments (Patterson 2005). Among the opportunistic mycoses, Candida albicans, Cryptococcus neoformans, and Aspergillus fumigatus are the most common invasive mycoses in these patients (Pfaller et al. 2006). The estimated annual incidence of invasive mycoses is 72-290 infections per million population for Candida, 30-66 infections per million for C. neoformans, and 12-34 
infections per million population for Aspergillus species (Pfaller and Diekema 2010). Although antifungal drugs such as deoxycholate amphotericin B, triazoles, itraconazole, and voriconazole are used for the treatment of invasive fungal infections, these drugs cause side effects such as nephrotoxicity, hepatotoxicity, and hazardous drug interactions (Maertens et al. 2004). Therefore, development of new antifungal agents is needed for the safe and effective treatment of invasive fungal infections.

Recently, Wang et al. (2012) isolated and elucidated nortriterpene glycoside and triterpene glycosides with antifungal properties from the ethanolic extracts of sea cucumber. The chemical structure of eight compounds such as 26-nor-25-oxo-holotoxin A1, $\left(\mathrm{C}_{65} \mathrm{H}_{102} \mathrm{O}_{32} \mathrm{Na}\right.$, 1417.6252) holotoxin $\mathrm{D}\left(\mathrm{C}_{66} \mathrm{H}_{104} \mathrm{O}_{32} \mathrm{Na}, 1431.6408\right)$, holotoxin $\mathrm{E} \quad\left(\mathrm{C}_{65} \mathrm{H}_{102} \mathrm{O}_{31} \mathrm{Na}, 1401.6313\right)$, holotoxin $\mathrm{F}$ $\left(\mathrm{C}_{59} \mathrm{H}_{96} \mathrm{O}_{25} \mathrm{Na}\right.$, 1227.6138) and holotoxin $\mathrm{G}\left(\mathrm{C}_{58} \mathrm{H}_{94} \mathrm{O}_{25} \mathrm{Na}\right.$, 1213.5982) with three known holotoxin $\mathrm{A} 1$ and $\mathrm{B}$, and cladoloside B were identified by HPLC, NMR, and MS. According to their results, although some compounds (1, 4, and 5) exhibited selective potent antifungal activities against six fungal strains such as Candida albicans, C. tropicalis, Cryptococcus neoformans, Trichophyton rubrum, Microsporum gypseum, and Aspergillus fumigatus, the 18(20) lactone group and the $\Delta^{25}$ terminal double bond may increase the activity.

\section{Anti-hyperlipidemic activity}

Hyperlipidemia is one of the risk factors contributing to the development and progression of cardiovascular diseases including coronary heart disease (Machado et al. 2008). Hyperlipidemia is characterized by the increased total cholesterol and triglycerides, low density lipoprotein (LDL), very low density lipoprotein (VLDL), and decreased high density lipoprotein (HDL) (Huang et al. 2006). The LDL is the major transporter of cholesterol to peripheral cells, while HDL returns the excess tissue cholesterol to the liver by reverse cholesterol transport (Ikonen 2008). Although lipid-lowering drugs such as HMG-CoA reductase inhibitors, fibrates and bile acidsequestering resins have been used for the treatment of hyperlipidemia, these drugs have side effects such as liver steatosis or hypertriglyceridemia ( $\mathrm{Li}$ et al. 2015). Therefore, development of a safe and effective treatment for hyperlipidemia is still a challenge to the current medical therapy.

The polysaccharides from $A$. japonicus (AJP) were extracted by the protease hydrolysis method and tested for anti-hyperlipidemic activity in vivo experiment by Lui et al. (2012b). The AJP extract was mainly composed of glucosamine, galactosamine, glucuronic acid, mannose, glucose, galactose, and fucose, with a molecular weight of about $36.2 \mathrm{kDa}$. The anti-hyperlipidemic activity of AJP at 200, 400, and $800 \mathrm{mg} / \mathrm{kg}$ was investigated by serum total cholesterol (TC), triglyceride (TG), LDLcholesterol (LDL-C) and HDL-cholesterol (HDL-C) using an enzymatic colorimetric method in hyperlipidemic Wistar rats for 28 days. The rats fed with AJP at $400 \mathrm{mg} /$ $\mathrm{kg}$ showed that TC, TG, and LDL-C concentrations decreased significantly by $17.23,20.78$, and $31.18 \%$, respectively, and HDL-C increased by $27.27 \%$ as compared to the hyperlipidemic group. Although, the mechanism of AJP on anti-hyperlipidemic activity needs to be still clarified, AJP could be a potential therapeutic target for hyperlipidemia.

\section{Anti-inflammation}

The inflammatory response is one of the most important defense mechanism for protection during microbial infection and tissue injury. During the inflammatory process, macrophages are activated by endogenous and exogenous factors, which release various proinflammatory factors such as nitric oxide (NO) from inducible NO synthase (iNOS) and prostaglandin E2 (PGE2) from cyclooxygenase-2 (COX-2), and cytokines such as interleukins, IL-1 $\beta$, IL- 6 , and tumor necrosis factor (TNF- $\alpha$ ) (Xu et al. 2014). Normally, inflammatory and healing processes are interrelated. The factors responsible for inflammatory response are also involved in the healing process. The excessive host inflammatory response by the overproduction of inflammatory mediators can lead to various diseases such as asthma, rheumatoid arthritis, psoriatic arthritis, systemic lupus erythematosus, Crohn's disease, multiple sclerosis, and systemic vasculitis (Tung et al. 2008). Therefore, anti-inflammatory activity is an important therapeutic strategy for various inflammatory diseases.

Himaya et al. (2010) extracted the ethyl acetate fraction from $S$. japonicus (SCEA-F) by solvent fraction and tested for the anti-inflammatory activity through $\mathrm{NO}$ and PGE2 production assay, iNOS and COX-2 protein and gene expression level, pro-inflammatory cytokines expression level (IL-1 $\beta$ and TNF- $\alpha$ ) and mitogenactivated protein kinases (MAPK, ERK, and p38 MAPK) on lipopolysaccharide (LPS)-induced murine macrophages. The results show that SCEA-F has a higher inflammatory activity as compared with another solvent fraction (hexane, chloroform, and butanol) in a dosedependent manner. In addition, SCEA-F inhibited the ERK and p38 MAPK phosphorylation in LPS-induced macrophage cells. Similarly, the anti-inflammatory activity of solvent fraction from $S$. japonicus was investigated by Park et al. (2011). The result showed that ethyl acetate (EtOAc) fractions exhibited strong anti-inflammatory activity as compared with another solvent fraction. Thus, ethyl acetate fractions from $S$. japonicus could be used as an effective anti-inflammation agent. 


\section{Anti-melanogenesis}

Melanogenesis is the process of melanin synthesis by a cascade of enzymatic reactions that convert tyrosine to melanin pigments such as eumelanin, pheomelanin, neuromelanin, and mixed melanin pigment (Slominski et al. 2004). Melanin is a mixture of pigmented biopolymers synthesized in specialized cells known as melanocytes by melanin synthesis related enzymes such as tyrosinase, TRP-1 and TRP-2 (Ito 2003). It provides the color of the animal skin, hair, and eyes and protects against the harmful effect of UV radiation. However, the overproduction of melanin causes serious esthetic problems such as freckle, liver spots and melasma (Oh et al. 2015). In the melanin synthesis related enzymes, tyrosinase is the rate-limiting enzyme and plays a critical regulatory role in the first step of melanogenesis (Qiao et al. 2012). Therefore, inhibition of tyrosinase is one of the important treatment methods of esthetic problems. Although, tyrosinase inhibitors including hydroquinone, kojic acid, azelaic acid, electron-rich phenols and arbutin have been used for the treatment of abnormal pigmentation through inhibition of converting tyrosine to L-dihydroxyphenylalanine (L-DOPA), these tyrosinase inhibitors have many side effects such as skin irritation, cytotoxic to melanocytes, carcinogenicity, low formulation stability and poor skin penetration (Chen et al. 2015).

Yoon et al. (2010) evaluated the anti-melanogenesis activity of the ethanolic extracts and solvent-partitioned fractions ( $n$-hexane, $\mathrm{CHCl}_{3}, \mathrm{EtOAc}, \mathrm{BuOH}$, and water) from $S$. japonicus. The results indicate that EtOAc causes the highest reduction of melanin content and the expression of melanogenesis-related proteins (tyrosinase, TRP-1, TRP-2, and MITF) in B16 cells. Furthermore, it has been shown that $S$. japonicus extract did not cause any severe adverse reactions on human skin by conducting patch tests for 2 to 3 days. In another study, Husni et al. (2011) isolated and elucidated the two tyrosinase inhibitors from the ethanol and water extracts of S. japonicus body wall by HPLC and NMR. The results show that ethanol extracts exhibited higher tyrosinase inhibitory activity than the water extracts. Compound 1 (adenosine) had molecular weight of $267.241 \mathrm{~g} / \mathrm{mol}$ $\left(\mathrm{C}_{10} \mathrm{H}_{13} \mathrm{~N}_{5} \mathrm{O}_{4}\right)$ and compound 2 (ethyl- $\alpha$-D-glucopyranoside) had molecular weight of $208.209 \mathrm{~g} / \mathrm{mol}\left(\mathrm{C}_{8} \mathrm{H}_{16} \mathrm{O}_{6}\right)$. Regarding the tyrosinase inhibitory effects, adenosine and ethyl- $\alpha$-D-glucopyranoside has $\mathrm{IC}_{50}$ value of 0.191 and $0.126 \mathrm{mg} / \mathrm{ml}$, respectively. In addition, $\mathrm{Oh}$ et al. (2017) investigated the effects of $S$. japonicus extracts on melanogenesis in B16F10 and Melan-A cells. The results indicated that ethanol extracts cause the reduction expression level of tyrosinase, TRP-1, TRP-2, and MITF by phosphorylation of ERK. Therefore, sea cucumber may be a good source for natural tyrosinase inhibitors.

\section{Anti-osteoclastogenesis}

Bone is a dynamic tissue playing support functions and physical protection of organs and is constantly remodeled throughout life. The bone formation and resorption remodeling process are tightly coupled, and bone homeostasis is maintained by the balance between bone formation by osteoblast and bone resorption by osteoclast (Pederson et al. 2008). Exceed bone resorption can lead to metabolic bone diseases such as osteoporosis (Cuong et al. 2010). Osteoporosis is characterized by reduction in bone mineral density due to excessive bone resorption by osteoclasts. Although several anti-resorptive drugs such as alendronate, risedronate, ibandronate, zoledronic acid, raloxifene and strontium ranelate are used for osteoporosis, their use is limited by a number of side effects, such as oesophageal irritation, acute-phase reaction, hypocalcaemia, potential renal toxic effects and thromboembolic disease (Rachner et al. 2011). Therefore, new safe and effective antiresorptive drugs are needed.

Kariya et al. (2004) isolated the two types of fucan sulfate from chloroform/methanol extract of $S$. japonicus body wall. They used NMR spectroscopy to elucidate the structure of fucan sulfite A and B. Type A contains $3.41 \mathrm{mmol}$ fucose $/ \mathrm{g}$ and $2.35 \mathrm{mmol}$ sulfate $/ \mathrm{g}$ and had a molecular mass of $9 \mathrm{kDa}$. Another type $\mathrm{B}$ contained $3.90 \mathrm{mmol}$ fucose $/ \mathrm{g}$ and $3.07 \mathrm{mmol}$ sulfate $/ \mathrm{g}$ and had a molecular mass of $32 \mathrm{kDa}$. In the in vitro assay for osteoclast formation, types A and B fucan sulfate inhibited osteoclast-like cell formation by 99.8 and $96.3 \%$, respectively. These results suggest that fucan sulfates A and B have great potential to be used as a source for natural anti-osteoclastogenesis reagent.

\section{Anti-oxidation}

Reactive oxygen species (ROS) such as superoxide anion radical $\left(\mathrm{O}_{2}^{-}\right)$, hydrogen peroxide $\left(\mathrm{H}_{2} \mathrm{O}_{2}\right)$ and hydroxyl radicals $\left({ }^{\circ} \mathrm{OH}\right)$ are continuously generated in normal oxygen consuming metabolic process. They operate as intracellular signaling molecules and protect from microbial infection (Fang 2004). Usually, the ROS are controlled by the free radical scavenging enzymes that convert superoxide anions to hydrogen peroxide $\left(\mathrm{Mn}^{2+}\right.$-dependent superoxide dismutase [MnSOD] and copper/zinc $[\mathrm{Cu} / \mathrm{Zn}] \mathrm{SOD})$ and hydrogen peroxide to water (glutathione peroxidase [GPx] and catalase [CAT]) and glutathione reductase (GR) (Wei and Lee 2002). However, overproduction of ROS by the environmental factor such as ionizing, UV radiation or numerous compounds can cause oxidative damage to biomacromolecules such as lipids, proteins, and nucleic acids by affecting the cells defense capacity (Cabiscol et al. 2000). Oxidative stress by overproduction of ROS can cause many age-dependent diseases such as 
atherosclerosis, osteoarthritis, neurodegenerative disorders (including Parkinson's disease, Alzheimer's disease, amyotrophic lateral sclerosis, and Huntington's disease) and cancer (Bickers and Athar 2006; Lin and Beal 2006). Therefore, anti-oxidant compounds are the most important factors for restoration and protection of the human body from oxidative damage.

The antioxidant activities of four types of sea cucumber extracts have been investigated by Husni et al. (2009). The sea cucumber extracts were prepared by performing heat reflux and pressurized solvent extractions with two solvents such as water and $70 \%$ ethanol. The antioxidant activities were evaluated by 2, 2diphenyl-1-picrylhydrazyl (DPPH) and 2, 2-azinobis (3ethylbenzothiazoline-6-sulfonic acid) (ABTS) radical scavenging activities. They suggested that the water or $70 \%$ ethanol extract by simple heat reflux extraction could have contributed to the antioxidant benefits. In another investigation, low-molecular-weight gelatin hydrolysate (LMW-GH, 700-1700 Da) was extracted from the body wall of $S$. japonicus by hydrolyzation with flavourzyme (Wang et al. 2010). The LMW-GH exhibited high superoxide and hydroxyl radical scavenging activity in a dose-dependent manner. The $\mathrm{IC}_{50}$ value of superoxide and hydroxyl radicals were 442 and $285 \mu \mathrm{g} / \mathrm{ml}$, respectively. Zheng et al. (2012) identified an antioxidative oligopeptide from autolysis hydrolysates of S. japonicus guts. Two tetrapeptides Val-Thr-Pro-Tyr (497 Da), ValLeu-Leu-Tyr (507 Da) and a hexapeptide Val-Gly-ThrVal-Glu-Met $(635 \mathrm{Da})$ were elucidated by ESI-MS/MS and exhibited antioxidant activities by the protection of hydroxyl radical-induced DNA damage. These oligopeptides exhibited protective barrier against hydroxyl radical-induced DNA damage at a concentration of $2 \mathrm{mg} / \mathrm{ml}$. Zhou et al. (2012) also studied the antioxidant activity of a novel peptide from $S$. japonicus by hydrolyzation with trypsin. The peptide was sequenced as GPEPTGPTGAPQWLR and $\mathrm{IC}_{50}$ values of hydroxyl and superoxide radical scavenging activity were 138.9 and $353.9 \mu \mathrm{M}$, respectively. Zhu et al. (2012) extracted a high-purity pepsin-solubilized collagen (PSC) from S. japonicus body wall and studied its hydroxyl and DPPH radical scavenging activities. The results showed that PSC has significantly higher hydroxyl and $\mathrm{DPPH}$ radical scavenging activities than that of vitamin C. In addition, AJP was also investigated for antioxidant activities such as DPPH, hydroxyl and superoxide radicals, and reducing power by Lui et al. (2012b). Therefore, $S$. japonicus has great potential as a source for natural antioxidant.

\section{Immunomodulatory effect}

The innate immune system is composed of many interdependent cell types and mediators, and is one of the most important natural systems for protection against a large number of harmful bacteria, viruses, parasites and fungi in human health and against autoimmune diseases, cancer, allergy and infection (Arron and Choi 2000; Kim et al. 2007a). In particular, preliminary studies have shown large evidence supporting the complex interaction between the immune system and the tumor (Marcus et al. 2014). A number of innate system immunomodulators have been identified; these include cytokines (interleukins, interferons, and chemokines), substances isolated from microorganisms and fungi (lipopolysaccharide), and substances isolated from plants (polysaccharides and phenolic compounds) (Schepetkin et al. 2009). In case of a tumor, tumor cells secrete the altered protein products that must be recognized as foreign by the immune effector cells such as $\mathrm{B}, \mathrm{T}$, natural killer and natural killer T cells, and type I and II interferons, and perforin which are able destroy tumor cells (Kim et al. 2007b; Hendry et al. 2016). Therefore, the enhancement of host immune response is one of the most important methods for inhibiting tumor growth and maintaining cellular homeostasis without harming the host.

Song et al. (2013) evaluated the immunomodulatory effect of S. japonicus acid mucopolysaccharide (SJAMP) in an experimental hepatocellular carcinoma model in rats. Rats were divided into five groups such as normal control, tumor control, low-SJAMP-dose $(17.5 \mathrm{mg} / \mathrm{kg})$, medium-SJAMP-dose $(35 \mathrm{mg} / \mathrm{kg})$ and high-SJAMP-dose $(70 \mathrm{mg} / \mathrm{ml})$. The results showed that SJAMP treatment groups had significantly reduced nodule volume and nodule number, serum $\alpha$-fetoprotein level, proliferating cell nuclear antigen expression, IL- 2 and TNF- $\alpha$, and increased levels of p21 expression. In addition, SJAMP recovered $\mathrm{CD}^{+}, \mathrm{CD}^{+}, \mathrm{CD}^{+}$and $\mathrm{CD}^{+} / \mathrm{CD}^{+}$on peripheral blood $\mathrm{T}$-lymphocyte subsets. In another study, Cao et al. (2017) extracted water soluble proteinsulfated fucan (PSF) complex from the body wall of $S$. japonicus and examined the immunomodulatory activity in RAW264.7 cells. The backbone structure of PSF was elucidated $(1 \rightarrow 3)$ - $\alpha$-L-linked fucosyl residue with sulfation at C-2 and/or C-4 by GC-MS and 2D-NMR. It has been shown that PSF and fractions significantly induced the mRNA expression of iNOS and cytokines generation including IL-6, IL-10, TNF- $\alpha$, and COX-2. Therefore, SJAMP can potentially provide the treatment and prevention of human diseases such as cancer and allergic disorders through immunomodulatory activity.

\section{Proliferative effect}

Regulation of cell proliferation plays a key role in treatment of various diseases or in tissue regeneration. Some studies support that sea cucumber regulates the cell proliferation. The cell viability and proliferation effects of sulfated polysaccharide (HS) in neural stem/progenitor 
cell (NSC) were demonstrated by Zhang et al. (2010b). The HS was extracted from $S$. japonicus by enzymolysis and subjected to fractionation by anion-exchange and gel-permeation chromatography. The average molecular weight of SJP was determined to be $4.23 \times 10^{5} \mathrm{Da}$ by analytical HPLC. SJP consist of $38.12 \%$ fucose, $16.52 \%$ uronic acid, $32.64 \%$ sulfate group and small amounts of galactose. The results showed that HS treatment with or without fibroblast growth factor-2 (FGF-2) increased NSC proliferation in a dose-dependent manner at concentrations of 200, 500 and $800 \mathrm{ng} / \mathrm{ml}$ without apoptosis. In another study, Sheng et al. (2011) demonstrated the morphological transformation and proliferation of rat astrocytes by HS $\left(4.23 \times 10^{5} \mathrm{Da}\right)$. Results demonstrated that although HS or FGF-2 alone did not show significant cell proliferation, combination of HS and FGF-2 significantly induced astrocytes morphological transformation, cell proliferation and cyclin D1 expression. In addition, Park et al. (2012) investigated cell proliferation by PSC from $S$. japonicus in comparison with rat PSC and bovine gelatin in $\mathrm{HaCaT}$ keratinocyte. In the cell migration assay, sea cucumber PSC coated plates induced more cell migration than gelatin coated plates or a non-coated plate, but similar to rat collagen coated plates. In addition, sea cucumber PSC enhanced fibronectin mRNA expression compared to that by rat collagen and gelatin. These results suggest that sea cucumber might be useful as an alternative to mammalian collagen and could be used for cell therapy in pharmaceutical industries.

\section{Neural related activities}

The mammalian central nervous system (CNS) is arguably one of the most complex systems in nature (Cao et al. 2006). Injury to the adult CNS is devastating because adult mammalian neurons do not regrow functional axons after damage and can lead to neuronal degeneration and cell death (Horner and Gage 2000). The CNS disorders such as Parkinson's disease, Huntington's disease, and stroke are induced by multiple genetic, environmental and other factors such as aging (Kazantsev and Thompson 2008). The NSC can treat the chronic injury of nerve as it can differentiate into mature neurons and glial cell lines and possess self-renewal ability (Cui et al. 2016b). Therefore, NSC is a major candidate for cell replacement therapy for various intractable CNS disorders.

Kaneko et al. (2003) isolated a new neuritogenic active ganglioside from $\mathrm{n}$-hexane fraction of chloroform/methanol extracts of $S$. japonicus and elucidated its chemical structure by GC-MS and NMR spectrum. The chemical structure of new ganglioside was elucidated NeuAc $2 \rightarrow 4($ NeuAc $\alpha 2 \rightarrow 3$ ) Gal $\beta 1 \rightarrow 8$ NeuAc $2 \rightarrow 3$ Gal$\mathrm{NAc} \beta 1 \rightarrow 3 \mathrm{Gal} \beta 1 \rightarrow 4 \mathrm{Glc} \beta 1 \rightarrow 1$ Cer. The new ganglioside was more neuritogenic than mammalian ganglioside in the rat pheochromocytoma cell line (PC12 cells). In another study, SJP $\left(4.23 \times 10^{5} \mathrm{Da}\right)$ evaluated the NSC proliferation and neurosphere formation by Zhang et al. (2010a). The results showed that SJP promotes the neurosphere formation by activating nuclear factor NF-kB in NSCs. Similarly, Sheng et al. (2012) extracted the sulfated polysaccharide from the $S$. japonicus (SJP) body wall and tested migration and differentiation of NSC. The average molecular weight of SJP was determined to be $1.79 \times 10^{5} \mathrm{Da}$ by HPSEC analysis. These results demonstrated that SJP treatment induced neurosphere adhesion migration by up-regulation of $\mathrm{N}$ cadherin and differentiation through the PI3K/Akt signaling pathway.

Cui et al. (2016c) evaluated NSC migration effect of SJP $\left(1.79 \times 10^{5} \mathrm{Da}\right)$. The result showed that SJP treatment with SDF-1 $\alpha / C X C R 4$ axis significantly induced the expression of MMP-2 and MMP-9 proteins and promoted NSC migration from the neurosphere through the PI3K/Akt/FOXO3a, ERK/MAPK and NF- $k B$ signaling pathways. Similarly, three types of polysaccharides including SJP $\left(1.79 \times 10^{5} \mathrm{Da}\right)$, fucoidan and heparin have been demonstrated in the NSC migration by Cui et al. (2016b). The results demonstrate that SJP, fucoidan and heparin treatment with SDF- $1 \alpha$ promoted NSC migration through the activation of PI3K/Akt/FOXO3a signaling pathway. Therefore, these polysaccharides can potentially be used for NSC cell therapy. The neuroprotective effect of SJP was investigated in a human dopaminergic neuroblastoma cell line (SH-SY5Y) by Cui et al. (2016a). They demonstrated that SJP inhibited cell death by 6-OHDA in SH-SY5Y through the inhibition of MAPK and NF- $\mathrm{KB}$ and the activation of PI3K/Akt signaling pathway in a dose-dependent manner at the concentrations of 75,150 and $300 \mu \mathrm{g} / \mathrm{ml}$ without cytotoxicity. In addition, Cui et al. (2015) investigated the protection effect of SJP on $\mathrm{Na}_{2} \mathrm{~S}_{2} \mathrm{O}_{4}$-induced hypoxia/ reoxygenation $(\mathrm{H} / \mathrm{R})$ injury in the $\mathrm{PC1} 2$ cell line. In $\mathrm{Na}_{2} \mathrm{~S}_{2} \mathrm{O}_{4}$-induced cell cytotoxicity, SJP treatment at $500 \mu \mathrm{g} / \mathrm{ml}$ induced cell viability to $64.7 \%$ as compared to the control cell viability of $46.8 \%$. Moreover, SJP treatment significantly reduced the $\mathrm{Bax} / \mathrm{Bcl}-2$ ratio, cleaved caspase3/caspase-3, p53 phosphorylation and cytochrome c release, and suppressed the activation of MAPKs such as JNK1/2 and p38 MAPK in a dose-dependent manner at 100,300 and $500 \mu \mathrm{g} / \mathrm{ml}$.

In another study, Shida et al. (2017) extracted fucosylayed chondroitin sulfate (FCS) and examined neurite outgrowth-promoting activity compared with shark cartilage CS-C [GlcA-GalNAc(4, 6-O-disulfate)] (0.5\%) and squid cartilage CS-E [GlcA-GalNAc(4, 6-O-disulfate)] (68\%). FCS consists of disulfated E unit [GlcA-Gal$\mathrm{NAc}(4$, 6-O-disulfate)] (48\%), monosulfated units $\mathrm{C}$ 
[GlcA-GalNAc(6-O-sulfated)] (28\%), monosulfated units A [GlcA-GalNAc(4-O-sulfate)] (12\%), and non-sulfated unit O [GlcA-GalNAc] (12\%). The results show that FCS exhibited higher neurite outgrowth-promoting activity than CS-C. Thus, SJP could be a potential novel therapeutic target for the treatment of CNS disorders with fewer side effects.

\section{Biomedical application}

Tissue engineering is an emerging multidisciplinary science that incorporates the principle of engineering, biochemistry, and biological sciences. The purpose of the tissue engineering is to restore, maintain, improve, or replace tissues and organs function of injury or disease tissues and organs. In tissue engineering, the scaffold is one of the most important factors to provide a space for cell attachment, proliferation, differentiation and tissue formation. Therefore, a scaffold must have an interconnected pore network, optimal pore size for tissue ingrowth, biocompatibility, hydrophilicity for cell-scaffold interaction and non-toxicity (Cai et al. 2002; Li et al. 2005). The polymer selection for scaffold fabrication should be cautiously considered because the mechanical or physiological properties depend on different types of polymer (Gunn and Zhang 2010).

Polymer can be divided into natural polymer and synthetic polymer. Among the natural polymers, collagen is the main component of extracellular matrix that contributes to mechanical property of cellular environments such as tissues and organs and constitutes approximately $30 \%$ of total proteins in the animal body (Pati et al. 2010). At least 29 unique collagen types (type I to XXIX) are encoded by at least 44 genes and determined by domains that required for repeating amino acid pattern of the Gly-X-Y triple helical domain (Schegg et al. 2009; Chandika et al. 2016). Commercial collagen is normally isolated from land-animal tissue origin, such as bovine and porcine skins and has been used for various industrial application such as food, cosmetic, pharmaceutical and biomedical products because of its excellent biocompatibility, biodegradability and non-immunogenicity (Chen et al. 2010; Liu et al. 2012a). However, the collagen from land-derived animal has shown to be contaminated with the infectious agents causing diseases such as bovine spongiform encephalopathy (BSE), transmissible spongiform encephalopathy (TSE) and foot-and-mouth disease (FMD). Therefore, various studies have focused on the extraction of marine-derived collagen and have characterized its properties as a good alternative to landanimal collagen because marine species do not promote zoonosis in humans (Uriarte-Montoya et al. 2010; Muralidharan et al. 2013).
The body wall of sea cucumber is a major edible part. The body wall proteins consist of $70 \%$ insoluble collagen and $30 \%$ non-collagenous fibers (Wu et al. 2013). Saito et al. (2002) isolated PSC from S. japonicus body wall and characterize it by amino acid composition and SDS-PAGE. The amino acid composition showed that glycine, hydroxyproline, and hydroxylysine are the major components in the collagen. They also showed that PSC from S. japonicus was similar to, but slightly different from the collagens from sea urchin and starfish. In another study, Cui et al. (2007) isolated PSC from S. japonicus body wall and characterized it in comparison with calf skin type I collagen. The characterization was investigated by amino acid compositions, UV-Vis spectrum, SDSPAGE patterns, peptide mapping and differential scanning calorimetry (DSC). They reported that although PSC has different peptide mapping and lower thermal stability temperature due to the different amino compositions as compared to calf skin type I collagen, it might be a useful alternative to landderived type I collagen because of being closer to that of calf skin collagen.

Sulfated polysaccharides have diverse functions such as development, cell differentiation, cell adhesion, cell signaling and cell matrix interactions due to their binding ability with proteins in the tissues (Senni et al. 2011). Therefore, they have been found an important role in pharmaceutical and biomedical application. Among the sulfated polysaccharides, fucoidan contains substantial percentages of L-fucose and sulfate ester groups and can be extracted from several algae or marine invertebrates such as sea cucumber or sea urchin (Li et al. 2008, Holtkamp et al. 2009). The structure of fucoidan principally consists of a backbone of $\alpha(1 \rightarrow 3)$ - and $\alpha(1 \rightarrow 4)$-linked $\alpha$-l-fucopyranose residues, which may be substituted with sulfate on the C-2 or/and C-3, C-4 (Ale and Meyer 2013). The fucoidans play an important role in several biological functions including antitumor and immunomodulatory, antithrombotic and anticoagulant, antiinflammation and antioxidant effects (Ale et al. 2011).

$\mathrm{Yu}$ et al. (2015b) isolated the fucoidan from $A$, japonicus (Aj-FUC) and tested the rheological characteristics in comparison with sea cucumber Acaudina molpadioides fucoidan (Am-FUC). The chemical structure of Aj-FUC was mainly consists of a novel repeating unit $[\alpha-\mathrm{L}-\mathrm{Fuc} p 2$ $\left(\mathrm{OSO}_{3}^{-}\right)-1 \rightarrow 3,(\alpha-\mathrm{L}-\mathrm{Fuc} p-1 \rightarrow 4-\alpha-\mathrm{L}-\mathrm{Fuc} p-1 \rightarrow) 4-\alpha-$ $\left.\mathrm{L}-\mathrm{Fuc} p 2\left(\mathrm{OSO}_{3}^{-}\right)-1 \rightarrow 3-\alpha-\mathrm{L}-\mathrm{Fucp} 2\left(\mathrm{OSO}_{3}^{-}\right)\right]$. The molecular weight of Aj-FUC was determined to be $1970 \mathrm{kDa}$ with a content of $23.2 \pm 3.7 \%$. Aj-FUC has lower viscosity than Am-FUC at the same concentration and shear rate. These results suggested that repeated branched unit might significantly influence the rheological characteristics of fucoidan. 


\section{Economic value of sea cucumber}

In the recent decades, invertebrate fisheries have expanded in catch and value worldwide (Anderson et al. 2011). Among the invertebrates, sea cucumber catch is exported to Hong Kong or nearby Asian countries and the sea cucumbers has risen dramatically in recent decades due to their potential health benefits to humans in the food, pharmaceutical and biomedical industrial areas (FAO 2008). On account of this reason, sea cucumber habitat and population are declining because of coastal fisheries pollution, and overfishing. Therefore, sea cucumber aquaculture and management is also one of the most important topic for solving of sea cucumber overfishing.

In case of sea cucumber $S$. japonicus, many researchers extracted various compound and biological extracts and investigated various biological activities related human health. However, still potential exists to isolate and identify new biological compounds from S. japonicus. Therefore, there is a need to fully identify and characterize the profile of new biological compounds from S. japonicus.

\section{Conclusions}

Sea cucumber belongs to the family Holothuroidea of the phylum Echinodermata. Among the sea cucumber, $S$. japonicus contains a number of bioactive materials such as fucan sulfate, bioactive peptide, gelatin, collagen, ganglioside, fatty acid, saponin, and acid mucopolysaccharides that exhibit various biological activities such as $\alpha$-glucosidase inhibition, anti-coagulation, anticancer, anti-fungal, anti-hyperlipidemic activity, antiinflammation, anti-melanogenesis, anti-osteoclastogenesis, anti-oxidant, immunomodulatory effect, proliferative effect, and neural related activities. In addition, the body wall of $S$. japonicus consist of collagen and polysaccharides and type I collagen and fucoidan can be extracted for application in the biomedical field. Therefore, sea cucumber S. japonicus has potential for use in pharmaceutical, food, and biomedical fields.

\footnotetext{
Abbreviations

ABTS: 2,2-azinobis (3-ethylbenzothiazoline-6-sulfonic acid); ADP-ribose: Poly (ADP-ribose) polymerase; Aj-FUC: Fucoidan from A, japonicus; AmFUC: Acaudina molpadioides fucoidan; APTT: Activated partial thromboplastin time; BCl-2: Prototypic anti-apoptotic protein; BSE: Bovine spongiform encephalopathy; CAT: Catalase; CNS: Central nervous system; COX2: Cyclooxygenase-2; Cu/Zn: Copper/zinc; DAHG: Depolymerized fucosylated chondroitin sulfate from S. japonicus; DPPH: 2,2-diphenyl-1-picrylhydrazyl; DSC: Differential scanning calorimetry; EtOAc: Ethyl acetate; FCS: Fucosylayed chondroitin sulfate; FGF-2: fibroblast growth factor-2; FMD: Foot-and-mouth disease; GPx: Glutathione peroxidase; GR: Glutathione reductase; H/ R: Hypoxia/reoxygenation; $\mathrm{H}_{2} \mathrm{O}_{2}$ : Hydrogen peroxide; $\mathrm{HDL}$ : High density lipoprotein; HDL-C: HDL-cholesterol; HS: Sulfated polysaccharide; INOS: Inducible NO synthase; LDL: Low density lipoprotein; LDL-C: LDLcholesterol; L-DOPA: L-dihydroxyphenylalanine; LMWH: Low molecular weight heparin; LPS: Lipopolysaccharide; MnSOD: $\mathrm{Mn}^{2+}$-dependent superoxide dismutase; $\mathrm{NO}$ : Nitric oxide; $\mathrm{O}_{2}^{-}$: Superoxide anion radical; $\mathrm{OH}$ : Hydroxyl radicals; PC12: Pheochromocytoma cell line; PGE2: prostaglandin E2; PSC: Pepsin-solubilized collagen; PSF: proteinsulfated fucan; PT: Prothrombin time; ROS: Reactive oxygen species; SCEA-
}

F: Ethyl acetate fraction from S. japonicus; SH-SY5Y: Human dopaminergic neuroblastoma cell line; SJAMP: Acid mucopolysaccharide from S. japonicus; SK-Mel-2: Human skin malignant melanocytomas; TC: Total cholesterol; TG: Triglyceride; TNF-a: Tumor necrosis factor; TSE: Transmissible spongiform encephalopathy; TT: Thrombin time; UE: Ultrasonification extraction; VLDL: Very low density lipoprotein

\section{Acknowledgements}

This research was financially supported by the research grant from the Korea Institute of Ocean Science and Technology (PO0129D) and was partially supported by the Jeju Special Self-Governing Province (PG49910).

\section{Funding}

This research was funded by the research grant from the Korea Institute of Ocean Science and Technology (PO0129D) and was funded by the Jeju Special Self-Governing Province (PG49910)

\section{Availability of data and materials}

Not applicable.

\section{Authors' contributions}

GWO and SCK designed this study and drafted the manuscript. DHL, SJH and WKJ conceived and designed the study, and also revised the manuscript. All authors read and approved the final manuscript.

Ethics approval and consent to participate

Not applicable.

\section{Consent for publication}

Not applicable.

\section{Competing interests}

The authors declare that they have no competing interests.

\section{Publisher's Note}

Springer Nature remains neutral with regard to jurisdictional claims in published maps and institutional affiliations.

\section{Author details}

${ }^{1}$ Department of Biomedical Engineering, and Center for Marine-Integrated Biomedical Technology (BK21 Plus), Pukyong National University, Busan 48513, Republic of Korea. ${ }^{2}$ Marine-Integrated Bionics Research Center, Pukyong National University, Busan 48513, Republic of Korea. ${ }^{3}$ Gyeongbuk Institute for Bio industry, Gyeongbuk 36728, Republic of Korea. ${ }^{4}$ Jeju International Marine Science Center for Research \& Education, Korea Institute of Ocean Science and Technology, Jeju 63349, Republic of Korea.

Received: 10 July 2017 Accepted: 26 September 2017

Published online: 02 November 2017

\section{References}

Ale MT, Meyer AS. Fucoidans from brown seaweeds: An update on structures, extraction techniques and use of enzymes as tools for structural elucidation. RSC Adv. 2013;3:8131-41.

Ale MT, Mikkelsen JD, Meyer AS. Important determinants for fucoidan bioactivity: a critical review of structure-function relations and extraction methods for fucose-containing sulfated polysaccharides from brown seaweeds. Mar Drugs. 2011;9:2106-30.

Alves RRN, Rosa IL. Animals in traditional folk medicine: implications for conservation. Berlin Heidelberg: Springer; 2012.

Anderson SC, Flemming JM, Watson R, Lotze HK. Serial exploitation of global sea cucumber fisheries. Fish Fish. 2011;12:317-39.

Arron JR, Choi Y. Osteoimmunology: bone versus immune system. Nature. 2000; 408:535-6.

Aydin M, Sevgili H, Tufan B, Emre Y, Kose S. Proximate composition and fatty acid profile of three different fresh and dried commercial sea cucumbers from Turkey. Int J Food Sci Technol. 2011;46:500-8.

Bai Y, Zhang L, Liu S, Ru X, Xing L, Cao X, Zhang T, Yang H. The effect of salinity on the growth, energy budget and physiological performance of green, white and purple color morphs of sea cucumber, Apostichopus japonicus. Aquaculture. 2015;437:297-303. 
Bickers DR, Athar M. Oxidative stress in the pathogenesis of skin disease. J Invest Dermatol. 2006;126:2565-75.

Bordbar S, Anwar F, Saari N. High-value components and bioactives from sea cucumbers for functional foods-a review. Marine Drugs. 2011;9:1761-805.

Cabiscol E, Tamarit J, Ros J. Oxidative stress in bacteria and protein damage by reactive oxygen species. Int Microb. 2000;3:3-8.

Cai Q, Yang J, Bei J, Wang S. A novel porous cells scaffold made of polylactidedextran blend by combining phase-separation and particle-leaching techniques. Biomaterials. 2002;23:4483-92.

Cao RA, Surayot U, You S. Structural characterization of immunostimulating protein-sulfated fucan complex extracted from the body wall of a sea cucumber, Stichopus japonicus. Int J Biol Macromol. 2017;99:539-48.

Cao X, Yeo G, Muotri AR, Kuwabara T, Gage FH. Noncoding RNAs in the mammalian central nervous system. Annu Rev Neurosci. 2006;29:77-103.

Chandika P, Ko S, Jung W. Marine-derived biological macromolecule-based biomaterials for wound healing and skin tissue regeneration. Int J Biol Macromol. 2015;77:24-35.

Chen WC, Tseng TS, Hsiao NW, Lin YL, Wen ZH, Tsai CC, Lee YC, Lin HH, Tsai KC. Discovery of highly potent tyrosinase inhibitor, $\mathrm{T} 1$, with significant antimelanogenesis ability by zebrafish in vivo assay and computational molecular modeling. Sci Rep. 2015;5:7995.

Chen Z, Wang P, Wei B, Mo X, Cui F. Electrospun collagen-chitosan nanofiber: A biomimetic extracellular matrix for endothelial cell and smooth muscle cell. Acta Biomater. 2010;6:372-82.

Chiasson JL, Josse RG, Gomis R, Hanefeld M, Karasik A, Laakso M, Group SNTR. Acarbose for prevention of type 2 diabetes mellitus: the STOP-NIDDM randomised trial. Lancet. 2002;359:2072-7.

Choi J, Seo JY, Lee SM. Effects of sources and levels of dietary carbohydrate on growth and body composition of juvenile sea cucumbers, Apostichopus japonicus. Fish Aquatic Sci. 2009;12:203-8.

Cui C, Cui N, Wang P, Song S, Liang H, Ji A. Sulfated polysaccharide isolated from the sea cucumber Stichopus japonicus against PC12 hypoxia/reoxygenation injury by inhibition of the MAPK signaling pathway. Cell Mol Neurobiol. 2015;35:1081-92

Cui C, Cui N, Wang P, Song S, Liang H, Ji A. Neuroprotective effect of sulfated polysaccharide isolated from sea cucumber Stichopus japonicus on 6-OHDAinduced death in SH-SY5Y through inhibition of MAPK and NF-KB and activation of PI3K Akt signaling pathways. Biochem Bioph Res Co. 2016a;470:375-83.

Cui C, Wang P, Cui N, Song S, Liang H, Ji A. Stichopus japonicus polysaccharide, fucoidan, or heparin enhanced the SDF-1a/CXCR4 axis and promoted NSC migration via activation of the PI3K/Akt/FOXO3a signaling pathway. Cell Mol Neurobiol. 2016b;36:1311-29.

Cui C, Wang P, Cui N, Song S, Liang H, Ji A. Sulfated polysaccharide isolated from the sea cucumber Stichopus japonicus promotes the SDF-1a/CXCR4 axisinduced NSC migration via the PI3K/Akt/FOXO3a, ERK/MAPK, and NF-KB signaling pathways. Neurosci Lett. 2016c;16:57-64.

Cui FX, Xue CH, Li ZJ, Zhang YQ, Dong P, Fu XY, Gao X. Characterization and subunit composition of collagen from the body wall of sea cucumber Stichopus japonicus. Food Chem. 2007;100:1120-5.

Cuong NX, Nhiem NX, Thao NP, Nam NH, Dat NT, Anh HLT, Van Kiem P, Van Minh C, Won JH, Chung WY. Inhibitors of osteoclastogenesis from Lawsonia inermis leaves. Bioorg Med Chem Lett. 2010;20:4782-4.

Dong P, Xue CH, Yu LF, XU J, Chen SG. Determination of triterpene glycosides in sea cucumber (stichopus japonicus) and its related products by highperformance liquid chromatography. J Agric Food Chem. 2008;56:4937-42

Dong Y, Dong S, Tian X, Wang F, Zhang M. Effects of diel temperature fluctuations on growth, oxygen consumption and proximate body composition in the sea cucumber Apostichopus japonicus Selenka. Aquaculture. 2006;255:514-21.

Du H, Bao Z, Hou R, Wang S, Su H, Yan J, Tian M, Li Y, Wei W, Lu W. Transcriptome sequencing and characterization for the sea cucumber Apostichopus japonicus (Selenka, 1867). PLoS One. 2012;7:e33311.

Duan X, Zhang M, Mujumdar AS, Wang S. Microwave freeze drying of sea cucumber (Stichopus japonicus). J Food Eng. 2010;96:491-7.

Dupont S, Ortega-Martínez O, Thorndyke M. Impact of near-future ocean acidification on echinoderms. Ecotoxicology. 2010;19:449-62.

Evan Gl, Vousden KH. Proliferation, cell cycle and apoptosis in cancer. Nature. 2001;411:342-8

Fang FC. Antimicrobial reactive oxygen and nitrogen species: concepts and controversies. Nat Rev Microbiol. 2004;2:820-32.
FAO. Sea cucumbers: A global review of fisheries and trade. Rome: Technical Report 516, Food and Agriculture Organization of the United Nations; 2008.

Ferdouse F. World markets and trade flows of sea cucumber/beche-de-mar. In: Advances in sea cucumber aquaculture and management. Rome: Food and Agriculture Organization of the United Nations; 2004. p. 101-16.

Gailani D, Renné T. Intrinsic pathway of coagulation and arterial thrombosis. Arterioscl Throm Vas. 2007;27:2507-13.

Gao F, Xu Q, Yang H. Seasonal biochemical changes in composition of body wall tissues of sea cucumber Apostichopus japonicus. Chin J Oceanol Limn. 2011a; 29:252-60.

Gao QF, Wang Y, Dong S, Sun Z, Wang F. Absorption of different food sources by sea cucumber Apostichopus japonicus (Selenka)(Echinodermata: Holothuroidea): evidence from carbon stable isotope. Aquaculture. 2011b; 319:272-6.

Gunn J, Zhang M. Polyblend nanofibers for biomedical applications: perspectives and challenges. Trends Biotechnol. 2010;28:189-97.

Hendry SA, Farnsworth RH, Solomon B, Achen MG, Stacker SA, Fox SB. The Role of the Tumor Vasculature in the Host Immune Response: Implications for Therapeutic Strategies Targeting the Tumor Microenvironment. Front Immunol. 2016;7:621.

Heo SJ, Hwang JY, Choi JI, Han JS, Kim HJ, Jeon YJ. Diphlorethohydroxycarmalol isolated from Ishige okamurae, a brown algae, a potent a-glucosidase and aamylase inhibitor, alleviates postprandial hyperglycemia in diabetic mice. Eur J Pharmacol. 2009;615:252-6.

Himaya S, Ryu B, Qian ZJ, Kim SK. Sea cucumber, Stichopus japonicus ethyl acetate fraction modulates the lipopolysaccharide induced iNOS and COX-2 via MAPK signaling pathway in murine macrophages. Environ Toxicol Phar. 2010;30:68-75.

Holtkamp AD, Kelly S, Ulber R, Lang S. Fucoidans and fucoidanases_focus on techniques for molecular structure elucidation and modification of marine polysaccharides. Appl Microbiol Biot. 2009;82:1.

Horner PJ, Gage FH. Regenerating the damaged central nervous system. Nature. 2000;407:963-70.

Huang THW, Peng G, Li GQ, Yamahara J, Roufogalis BD, Li Y. Salacia oblonga root improves postprandial hyperlipidemia and hepatic steatosis in Zucker diabetic fatty rats: activation of PPAR-a. Toxicol Appl Pharm. 2006;210:225-35.

Husni A, Jeon JS, Um BH, Han NS, Chung D. Tyrosinase inhibition by water and ethanol extracts of a far eastern sea cucumber, Stichopus japonicus. Food Sci Biotechnol. 2011;91:1541-7.

Husni A, Shin IS, You S, Chung D. Antioxidant properties of water and aqueous ethanol extracts and their crude saponin fractions from a far-eastern sea cucumber, Stichopus japonicus. Food Sci Biotechnol. 2009;18:419-24.

Ikonen E. Cellular cholesterol trafficking and compartmentalization. Nat Rev Mol Cell Bio. 2008:9:125-38.

Ito S. A chemist's view of melanogenesis. Pigment Cell Res. 2003;16:230-6.

Jiang S, Dong S, Gao Q, Wang F, Tian X. Comparative study on nutrient composition and growth of green and red sea cucumber, Apostichopus japonicus (Selenka, 1867), under the same culture conditions. Aquac Res. 2013:44:317-20.

Jo J, Park C, Kim M, Park C. Phylogenetic Analysis of the Three Color Variations of the Sea Cucumber Apostichopus japonicus. J Aquac Res Development. 2016;7:2.

Kaneko M, Kisa F, Yamada K, Miyamoto T, Higuchi R. Structure of a New Neuritogenic-Active Ganglioside from the Sea Cucumber Stichopus japonicus. European J Org Chem. 2003;2003:1004-8.

Kan-no M, Kijima A. Genetic differentiation among three color variants of Japanese sea cucumber Stichopus japonicus. Fisheries Sci. 2003;69:806-12.

Kariya Y, Mulloy B, Imai K, Tominaga A, Kaneko T, Asari A, Suzuki K, Masuda H, Kyogashima M, Ishii T. Isolation and partial characterization of fucan sulfates from the body wall of sea cucumber Stichopus japonicus and their ability to inhibit osteoclastogenesis. Carbohydr Res. 2004;339:1339-46.

Kazantsev AG, Thompson LM. Therapeutic application of histone deacetylase inhibitors for central nervous system disorders. Nat Rev Drug Discov. 2008;7:854-68.

Kim J, Bentley PJ, Aickelin U, Greensmith J, Tedesco G, Twycross J. Immune system approaches to intrusion detection-a review. Nat Comput. 2007a;6:413-66.

Kim NY, Choi WY, Heo SJ, Kang DH, Lee HY. Anti-skin cancer activities of Apostichopus japonicus extracts from low-temperature ultrasonification process. J Healthc Eng. 2017;2017

Kim R, Emi M, Tanabe K. Cancer immunoediting from immune surveillance to immune escape. Immunology. 2007b;121:1-14.

Ko SH, Go S, Okorie OE, Kim YC, Lee S, Yoo GY, Bai SC. Preliminary Study of the Dietary a-Tocopherol Requirement in Sea Cucumber, Apostichopus japonicus. J World Aquacult Soc. 2009;40:659-66. 
Lee MH, Kim YK, Moon HS, Kim KD, Kim GG, Cho HA, Yoon NY, Sim KB, Park HY, Lee DS. Comparison on proximate composition and nutritional profile of red and black sea cucumbers (Apostichopus japonicus) from Ulleungdo (Island) and Dokdo (Island). Korea Food Sci Biotechnol. 2012;21:1285-91.

Li B, Lu F, Wei X, Zhao R. Fucoidan: structure and bioactivity. Molecules. 2008;13:1671-95.

Li L, Li Q. Effects of stocking density, temperature, and salinity on larval survival and growth of the red race of the sea cucumber Apostichopus japonicus (Selenka). Aquacult Int. 2010;18:447-60.

Li Y, Wang L, Liu Z, Li C, Xu J, Gu Q, Xu J. Predicting selective liver X receptor $\beta$ agonists using multiple machine learning methods. Mol BioSyst. 2015;11:1241-50.

Li Z, Ramay HR, Hauch KD, Xiao D, Zhang M. Chitosan-alginate hybrid scaffolds for bone tissue engineering. Biomaterials. 2005;26:3919-28.

Lin MT, Beal MF. Mitochondrial dysfunction and oxidative stress in neurodegenerative diseases. Nature. 2006:443:787-95.

Liu D, Liang L, Regenstein JM, Zhou P. Extraction and characterisation of pepsinsolubilised collagen from fins, scales, skins, bones and swim bladders of bighead carp (Hypophthalmichthys nobilis). Food Chem. 2012a;133:1441-8.

Liu X, Sun Z, Zhang M, Meng X, Xia X, Yuan W, Xue F, Liu C. Antioxidant and antihyperlipidemic activities of polysaccharides from sea cucumber Apostichopus japonicus. Carbohyd Polym. 2012b;90:1664-70.

Lu Y, Zhang BY, Dong Q, Wang BL, Sun XB. The effects of Stichopus japonicus acid mucopolysaccharide on the apoptosis of the human hepatocellular carcinoma cell line HepG2. Am J Med Sci. 2010;339:141-4.

Machado M, Nassor N, Bajcar JM, Guzzo GC, Einarson TR. Sensitivity of patient outcomes to pharmacist interventions. Part III: systematic review and metaanalysis in hyperlipidemia management. Ann Pharmacother. 2008;42:1195-207.

Mackman N, Tilley RE, Key NS. Role of the extrinsic pathway of blood coagulation in hemostasis and thrombosis. Arterioscl Throm Vas. 2007;27:1687-93.

Maddika S, Ande SR, Panigrahi S, Paranjothy T, Weglarczyk K, Zuse A, Eshraghi M, Manda KD, Wiechec E, Los M. Cell survival, cell death and cell cycle pathways are interconnected: implications for cancer therapy. Drug Resist Updat. 2007;10:13-29.

Maertens J, Raad I, Petrikkos G, Boogaerts M, Selleslag D, Petersen FB, Sable CA, Kartsonis NA, Ngai A, Taylor A. Efficacy and safety of caspofungin for treatment of invasive aspergillosis in patients refractory to or intolerant of conventional antifungal therapy. Clin Infect Dis. 2004;39:1563-71.

Marcus A, Gowen BG, Thompson TW, lannello A, Ardolino M, Deng W, Wang L, Shifrin $\mathrm{N}$, Raulet $\mathrm{DH}$. Recognition of tumors by the innate immune system and natural killer cells. Adv Immunol. 2014;122:91.

Mestechkina N, Shcherbukhin V. Sulfated polysaccharides and their anticoagulant activity: A review. Appl Biochem Micro. 2010;46:267-73.

Moller DE. New drug targets for type 2 diabetes and the metabolic syndrome. Nature. 2001;414:821-7.

Muralidharan N, Shakila RJ, Sukumar D, Jeyasekaran G. Skin, bone and muscle collagen extraction from the trash fish, leather jacket (Odonus niger) and their characterization. J Food Sci Tech. 2013;50:1106-13.

Nguyen TH, Um BH, Kim SM. Two Unsaturated Fatty Acids with Potent aGlucosidase Inhibitory Activity Purified from the Body Wall of Sea Cucumber (Stichopus japonicus). J Food Sci. 2011;76:H208-14.

Oh CT, Kwon TR, Jang YJ, Yoo KH, Kim BJ, Kim H. Inhibitory effects of Stichopus japonicus extract on melanogenesis of mouse cells via ERK phosphorylation. Mol Med Rep. 2017;16:1079-86.

Oh GW, Ko SC, Heo SY, Nguyen VT, Kim G, Jang CH, Park WS, Choi IW, Qian ZJ, Jung WK. A novel peptide purified from the fermented microalga Pavlova lutheri attenuates oxidative stress and melanogenesis in B16F10 melanoma cells. Process Biochem. 2015;50:1318-26.

Okorie OE, Ko SH, Go S, Lee S, Bae JY, Han K, Bai SC. Preliminary study of the optimum dietary ascorbic acid level in sea cucumber, Apostichopus japonicus (Selenka). J World Aquacult Soc. 2008;39:758-65.

Park SY, Lim HK, Lee S, Cho SK, Park S, Cho M. Biological effects of various solvent fractions derived from Jeju Island red sea cucumber (Stichopus japonicas). J Korean Soc Appl Biol Chem. 2011;54:718-24.

Park SY, Lim HK, Lee S, Hwang HC, Cho SK, Cho M. Pepsin-solubilised collagen (PSC) from Red Sea cucumber (Stichopus japonicus) regulates cell cycle and the fibronectin synthesis in HaCaT cell migration. Food Chem. 2012;132:487-92.

Pati F, Adhikari B, Dhara S. Isolation and characterization of fish scale collagen of higher thermal stability. Bioresour Technol. 2010;101:3737-42.

Patterson TF. Advances and challenges in management of invasive mycoses. Lancet. 2005;366:1013-25.
Pederson L, Ruan M, Westendorf JJ, Khosla S, Oursler MJ. Regulation of bone formation by osteoclasts involves Wnt/BMP signaling and the chemokine sphingosine-1-phosphate. Proc Natl Acad Sci U S A. 2008;105:20764-9.

Pfaller MA, Diekema DJ. Epidemiology of invasive mycoses in North America. Crit Rev Microbiol. 2010;36:1-53.

Pfaller MA, Pappas PG, Wingard JR. Invasive fungal pathogens: current epidemiological trends. Clin Infect Dis. 2006;43:S3-S14.

Purcell SW, Conand C, Uthicke S, Byrne M. Ecological roles of exploited sea cucumber. Oceanor Mar Biol. 2016;54:367-86.

Qiao Z, Koizumi Y, Zhang M, Natsui M, Flores MJ, Gao L, Yusa K, Koyota S, Sugiyama T. Anti-melanogenesis effect of Glechoma hederacea L. extract on B16 murine melanoma cells. Biosci Biotechnol Biochem. 2012;76:1877-83.

Rachner TD, Khosla S, Hofbauer LC. Osteoporosis: now and the future. Lancet. 2011;377:1276-87.

Saito M, Kunisaki N, Urano N, Kimura S. Collagen as the major edible component of sea cucumber (Stichopus japonicus). J Food Sci. 2002;67:1319-22.

Schegg B, Hülsmeier AJ, Rutschmann C, Maag C, Hennet T. Core glycosylation of collagen is initiated by two $\beta$ (1-O) galactosyltransferases. Mol Cell Biol. 2009;29:943-52.

Schepetkin IA, Kirpotina LN, Jakiw L, Khlebnikov Al, Blaskovich CL, Jutila MA Quinn MT. Immunomodulatory activity of oenothein B isolated from Epilobium angustifolium. J Immunol. 2009;183:6754-66.

Senni K, Pereira J, Gueniche F, Delbarre-Ladrat C, Sinquin C, Ratiskol J, Godeau G, Fischer AM, Helley D, Colliec-Jouault S. Marine polysaccharides: a source of bioactive molecules for cell therapy and tissue engineering. Mar Drugs. 2011;9:1664-81.

Seo JY, Shin IS, Lee SM. Effect of various protein sources in formulated diets on the growth and body composition of juvenile sea cucumber Apostichopus japonicus (Selenka). Aquac Res. 2011;42:623-7.

Sheng X, Li M, Song S, Zhang N, Wang Y, Liang H, Wang W, Ji A. Sulfated polysaccharide isolated from the sea cucumber Stichopus japonicus promotes neurosphere migration and differentiation via up-regulation of $\mathrm{N}$-cadherin. Cell Mol Neurobiol. 2012;32:435-42.

Sheng X, Zhang N, Song S, Li M, Liang H, Zhang Y, Wang Y, Ji A. Morphological transformation and proliferation of rat astrocytes as induced by sulfated polysaccharides from the sea cucumber Stichopus japonicus. Neurosci Lett. 2011;503:37-42.

Shida M, Mikami T, Ji T, Kitagawa H. A characteristic chondroitin sulfate trisaccharide unit with a sulfated fucose branch exhibits neurite outgrowth-promoting activity: Novel biological roles of fucosylated chondroitin sulfates isolated from the sea cucumber Apostichopus japonicus. Biochem Bioph Res Co. 2017:487:678-83.

Slominski A, Tobin DJ, Shibahara S, Wortsman J. Melanin pigmentation in mammalian skin and its hormonal regulation. Physiol Rev. 2004;84:1155-228.

Song Y, Jin SJ, Cui LH, Ji XJ, Yang FG. Immunomodulatory effect of Stichopus japonicus acid mucopolysaccharide on experimental hepatocellular carcinoma in rats. Molecules. 2013;18:7179-93.

Taylor SI. Deconstructing type 2 diabetes. Cell. 1999;97:9-12.

Tung YT, Chua MT, Wang SY, Chang ST. Anti-inflammation activities of essential oil and its constituents from indigenous cinnamon (Cinnamomum osmophloeum) twigs. Bioresour Technol. 2008;99:3908-13.

Uriarte-Montoya MH, Arias-Moscoso JL, Plascencia-Jatomea M, Santacruz-Ortega H, Rouzaud-Sández O, Cardenas-Lopez JL, Marquez-Rios E, Ezquerra-Brauer JM. Jumbo squid (Dosidicus gigas) mantle collagen: Extraction, characterization, and potential application in the preparation of chitosan-collagen biofilms. Bioresour Technol. 2010;101:4212-9.

Versteeg HH, Heemskerk JW, Levi M, Reitsma PH. New fundamentals in hemostasis. Physiol Rev. 2013;93:327-58.

Wang J, Wang Y, Tang Q, Wang Y, Chang Y, Zhao Q, Xue C. Antioxidation activities of low-molecular-weight gelatin hydrolysate isolated from the sea cucumber Stichopus japonicus. J Ocean U China. 2010;9:94-8.

Wang Z, Zhang H, Yuan W, Gong W, Tang H, Liu B, Krohn K, Li L, Yi Y, Zhang W. Antifungal nortriterpene and triterpene glycosides from the sea cucumber Apostichopus japonicus Selenka. Food Chem. 2012;132:295-300.

Wei YH, Lee HC. Oxidative stress, mitochondrial DNA mutation, and impairment of antioxidant enzymes in aging. Exp Biol Med. 2002;227:671-82.

Wu B, Xia S, Rahman M, Rajkumar M, Fu Z, Tan J, Yang A. Substituting seaweed with corn leaf in diet of sea cucumber (Apostichopus japonicus): Effects on growth, feed conversion ratio and feed digestibility. Aquaculture. 2015;444:88-92.

Wu HT, Li DM, Zhu BW, Sun JJ, Zheng J, Wang FL, Konno K, Jiang X. Proteolysis of noncollagenous proteins in sea cucumber, Stichopus japonicus, body wall: 
Characterisation and the effects of cysteine protease inhibitors. Food Chem. 2013;141:1287-94.

Xia B, Gao QF, Wang J, Li P, Zhang L, Zhang Z. Effects of dietary carbohydrate level on growth, biochemical composition and glucose metabolism of juvenile sea cucumber Apostichopus japonicus (Selenka). Aquaculture. 2015:448:63-70

Xu X, Yin P, Wan C, Chong X, Liu M, Cheng P, Chen J, Liu F, Xu J. Punicalagin inhibits inflammation in LPS-induced RAW264. 7 macrophages via the suppression of TLR4-mediated MAPKs and NF-KB activation. Inflammation. 2014;37:956-65.

Yang H, Zhou Y, Zhang T, Yuan X, Li X, Liu Y, Zhang F. Metabolic characteristics of sea cucumber Apostichopus japonicus (Selenka) during aestivation. J Exp Mar Biol Ecol. 2006;330:505-10.

Yang J, Wang Y, Jiang T, Lv L, Zhang B, Lv Z. Depolymerized glycosaminoglycan and its anticoagulant activities from sea cucumber Apostichopus japonicus. Int J Biol Macromol. 2015a;72:699-705.

Yang J, Wang Y, Jiang T, Lv Z. Novel branch patterns and anticoagulant activity of glycosaminoglycan from sea cucumber Apostichopus japonicus. Int J Biol Macromol. 2015b;72:911-8.

Yoon W, Kim M, Koh H, Lee W, Lee N, Hyun C. Effect of Korean red sea cucumber (Stichopus japonicus) on melanogenic protein expression in murine B16 melanoma. Int J Pharmacol. 2010;6:37-42.

Yu HB, Gao QF, Dong SL, Wen B. Changes in fatty acid profiles of sea cucumber Apostichopus japonicus (Selenka) induced by terrestrial plants in diets. Aquaculture. 2015a;442:119-24.

Yu L, Xue C, Chang Y, Hu Y, Xu X, Ge L, Liu G. Structure and rheological characteristics of fucoidan from sea cucumber Apostichopus japonicus. Food Chem. 2015b;180:71-6.

Zhang Y, Song S, Liang H, Wang Y, Wang W, Ji A. Enhancing effect of a sea cucumber Stichopus japonicus sulfated polysaccharide on neurosphere formation in vitro. J Biosci Bioeng. 2010a; 10:479-86.

Zhang Y, Song S, Song D, Liang H, Wang W, Ji A. Proliferative effects on neural stem/progenitor cells of a sulfated polysaccharide purified from the sea cucumber Stichopus japonicus. J Biosci Bioeng. 2010b;109:67-72.

Zheng J, Wu HT, Zhu BW, Dong XP, Zhang MM, Li YL. Identification of antioxidative oligopeptides derived from autolysis hydrolysates of sea cucumber (Stichopus japonicus) guts. Eur Food Res Technol. 2012;234:895-904.

Zhou X, Wang C, Jiang A. Antioxidant peptides isolated from sea cucumber Stichopus japonicus. Eur Food Res Technol. 2012;234:441-7.

Zhu BW, Dong XP, Zhou DY, Gao Y, Yang JF, Li DM, Zhao XK, Ren TT, Ye WX, Tan $H$. Physicochemical properties and radical scavenging capacities of pepsinsolubilized collagen from sea cucumber Stichopus japonicus. Food Hydrocolloid. 2012;28:182-8.

Zohdi RM, Zakaria ZAB, Yusof N, Mustapha NM, Abdullah MNH. Sea cucumber (Stichopus hermanii) based hydrogel to treat burn wounds in rats. J Biomed Mater Res B. 2011;98:30-7.

\section{Submit your next manuscript to BioMed Central and we will help you at every step:}

- We accept pre-submission inquiries

- Our selector tool helps you to find the most relevant journal

- We provide round the clock customer support

- Convenient online submission

- Thorough peer review

- Inclusion in PubMed and all major indexing services

- Maximum visibility for your research

Submit your manuscript at www.biomedcentral.com/submit
C Biomed Central 